\title{
First report of collar rot on Ananas lucidus caused by Athelia rolfsii in Brazil
}

\author{
Lucas Matheus Fonseca Almeida ${ }^{1}$. Naylla Cristina Oliveira Pinho ${ }^{1}$. Juliana Barral Moreira ${ }^{1}$. \\ Aricléia de Moraes Catarino ${ }^{2}(1) \cdot$ Cristiana Araujo Soares $^{3}$ (1) . João Victor Jansen de Queiroz ${ }^{3}[$
}

Received: 27 May 2020 / Accepted: 8 April 2021 / Published online: 19 April 2021

(c) Società Italiana di Patologia Vegetale (S.I.Pa.V.) 2021

Keywords Curagua $\cdot$ Southern blight $\cdot$ Wilting

Ananas lucidus Miller (Bromeliaceae) is an ornamental pineapple popularly known as curagua. This plant has great economic value for indigenous peoples of the Brazilian and Venezuelan Amazon, who use its fiber in local crafts. Therefore, it is important to know which diseases limit plant growth. During July 2017, on a curagua plantation (3 ha) in São José de Ribamar, Maranhão, Brazil, severe wilting was observed in approximately 300 plants. Pieces of tissue from 25 plants sampled with collar rot symptoms were sterilized and plated on potato dextrose agar (PDA) containing streptomycin sulfate $(0.5 \mathrm{~g} / \mathrm{l})$. All isolations were done at the same time. After 3 days of incubation at $26^{\circ} \mathrm{C}$, there were dense and cotton-like aerial mycelia on the dishes. After 21 days of incubation, the pure culture developed abundant globoid to irregular sclerotia, initially white and then brown with 1 to $3 \mathrm{~mm}$ diameter. Morphological characteristics of colonies on PDA were useful for identifying Athelia rolfsii (Curzi) Tu \& Kimbrough (anamorph Sclerotium rolfsii Sacc.) (Mordue 1974). The identity was confirmed by amplification and sequencing of a $703 \mathrm{bp}$ fragment of ITS region using ITS1/ITS4 primers (GenBank accession No. MT337402) (White et al. 1990). Bayesian inference

João Victor Jansen de Queiroz

jvjdqueiroz@gmail.com

Aricléia de Moraes Catarino

amoraescatarino@gmail.com

Cristiana Araujo Soares

criwann@gmail.com

1 Instituto de Educação, Ciência e Tecnologia do Maranhão, São José de Ribamar, MA, Brazil

2 Programa de Pós-Graduação em Agricultura no Trópico Úmido, Instituto Nacional de Pesquisas da Amazônia, Manaus, AM, Brazil

3 Departamento de Agricultura, Instituto de Educação, Ciência e Tecnologia do Maranhão, São José de Ribamar, MA, Brazil showed $100 \%$ identity with $A$. rolfsii (KT750883). Pathogenicity tests were conducted on 20 healthy curagua plants (from same genotype) with two months of development. Mycelial plugs with $0.5 \mathrm{~mm}$ diameter were deposited at the base of ten plants. Ten control plants received only sterile PDA plug. After 30 days at $(25 \pm 2){ }^{\circ} \mathrm{C}$, inoculated plants presented wilting similar to that observed in the field, and control plants showed no symptoms. A. rolfsii was re-isolated and identified morphologically from symptomatic tissue. This is the first occurrence of $A$. rolfsii causing collar rot in curagua in Brazil and in the world.

\section{References}

Mordue JE (1974) CMI Descriptions of Pathogenic Fungi and Bacteria. No. 410. CAB International, Wallingford

White T, Bruns T, Lee S, Taylor J (1990) Amplification and direct sequencing of fungal ribosomal RNA genes for phylogenetics. In: Innis MA, Gelfand DH, Sninsky JJ, White TJ (eds) PCR protocols: a guide to methods and applications. Academic Press, San Diego

Publisher's Note Springer Nature remains neutral with regard to jurisdictional claims in published maps and institutional affiliations. 